\title{
The progressive regional agenda for South America: the case of Mercosur and its borders
}

A agenda regional progressista para a América do Sul: o caso do Mercosul e suas fronteiras

Gustavo Matiuzzi de Souza ${ }^{1}$

\begin{abstract}
This work aims at exploring the relation between Mercosur's political agenda on borders and the local interactions at these spaces in the light of the 'left turn' in South America (2002-2014). This brief conjuncture analysis found that the 'regionalism by the left' did not foster structural changes in Mercosur nor resolved issues of coordination necessary for the border, regionalization dynamics to leave the informal sphere in which they reside.
\end{abstract}

Keywords: 'left turn'; borders of Mercosur; regionalism and regionalization

\section{RESUMO}

Este trabalho objetiva explorar a relação entre a agenda política do Mercosul no tocante a fronteiras e as interações de nível local nesses espaços sob a lógica da 'virada à esquerda' na América do Sul (2002-2014). Concluiu-se que o 'regionalismo pela esquerda' não fomentou reformas estruturais, nem solucionou problemas de coordenação, ambos necessários para que as interações na fronteira deixassem a esfera da informalidade.

Palavras-chave: 'virada à esquerda'; fronteiras do Mercosul; regionalismo e regionalização

\section{Introduction}

The present work aims at briefly exploring the relation between Mercosur's institutional political agenda concerning borders and border regions (top-down regional relations) and the local interactions at the 'micro'-level border regions as producers of demands (bottom-up regional relations) in the light of the 'left turn' in South America, in the period of 2002-2014. Beyond the institutionalist analysis, understanding the 'vertical relations' between different levels of the regional process requires looking into the specificities of regional dynamics influenced by the rise of

${ }^{1}$ PhD Candidate in Social Sciences at PUCRS (Brazil) and at University of Liège (Belgium). Researcher at the Center for International Relations Studies (CEFIR) and at the International Affairs and Organizations Study Nucleus (NEROI). CAPES Foundation Doctoral Scholar, \# 99999.010684/2014-00. Liège, Belgium. 
progressive (leftist) ${ }^{2}$ governments in the mentioned years. Thus, the objective of this work is to explore some of the consequences of this intertwined, intricate, and uneven construction of South America as a region, and more specifically, of Mercosur.

That is to say that the investigation will not focus on the processes of institutional (re)construction of Mercosur. Rather, it will aim at the functioning of such institutions that were, in the investigated years, subject to this diverse regional environment, which was built by and through the relations among leftist presidents and their interaction with society at local level.

In order to do this, the article will be divided in three main sections. Firstly, it is necessary to make some conceptual and analytical clarifications on the regionalist process for the case under this work's focus. Secondly, the article will concentrate on the analysis of the consequences of the 'left turn' to regionalism in South America and, more specifically, to Mercosur. Thirdly, this work will put light into the already established institutions within Mercosur that aimed at furthering border integration through the perspective of the politics generated by the presence of progressive governments. Lastly, some final remarks will conclude this study.

\section{Conceptual and analytical clarifications}

Borders, here defined as international limits between states, lie in the center of regionalism and regionalization processes due to its singular, diversified, and symbolic roles (HEYMAN \& SYMONS, 2012) through which diverse informal social, political, economic, and cultural interactions occur. The concept of 'regionalization', in turn, should be understood as the "informal process of regional interaction (economic, social, cultural, etc.) that takes place beyond the strictly national borders" (CABALLERO, 2015, p. 44). Regionalization happens then at the local level, as de facto cooperation or integration takes place. These local interactions (bottom-up regional processes) generates an intricate space - the border region - in which local populations are interrelated.

\footnotetext{
2 The development of this analysis does not imply a clear definition of 'left'. Rather, the important aspect to be analyzed here is the self-perception of elected presidents as 'progressive' or as 'to the left' of the political scale.
} 
Moreover, there at the border and within the border region "national and subnational governments share responsibilities and jurisdictions, and [...] regional organisms play a role of creating norms and of facilitating local processes of cooperation and/or integration" (MATIUZZI DE SOUZA, 2015a). In other words, borders are also a space in which regionalism takes place. 'Regionalism' here should be defined as "a political project tending to stimulate integration that is, based on the political will of the parties." (CABALLERO, 2015, p. 44) Regionalism, thus, functions at the top-level of formal political relations. It is also important to note that regionalism strongly depends, in the case of South America and principally in Mercosur ${ }^{3}$, on diplomatic negotiations among leaders of the Executive of each country involved in the process.

Border regions are, in this context, a central element to comprehend the regional space socially constructed by both formal and informal interactions (see SÖDERBAUM, 2013). Also, they are a space of ambiguity, since regionalism and regionalization function under different logics. For example, it is plausible to infer that, within the regional dynamics of South America, if a group of presidents (and other top-level policymakers) share as many opinions as possible about a political project, regionalism will likely succeed. That is to say that the 'left turn' is expected to facilitate the furthering of regionalism.

On the other hand, regionalization at border regions had happened, is happening, and will happen beyond the top-level agreements engendered by policymakers, although it is somewhat limited by them. Yet, local cross-border interactions, although informal (and at times illegal) have been used as a source of a regional identity construction, as an origin of shared values and culture, as a basis of a Mercosurness, and above all, as a space for the strengthening of the regional organism. The relationship between regionalism and regionalization, hence, implies a complex web of top-down and bottom-up regional negotiations (vertical relations) through which political and economic actors, as well as civil societies construct a region beyond (but also through) the process of institutionalization.

\footnotetext{
3 See Malamud (2003) for a thorough analysis on the relation of 'presidentialism' and the development of Mercosur as the most important regional organism in South America.
} 


\section{The progressive regional agenda}

After more than a decade under the so-called 'Washington Consensus' (from the end of the 1980s to the 2000s), which promoted neoliberalism and its economic and social policies, South America experienced the rise of governments of progressive sensibilities throughout the continent. The 'left turn', as the phenomenon was called, had a double effect on South American regionalism and regionalization: on the one hand, it gave the general feeling of a 'regional left' among presidents of the continent, and incorporated an amplified notion of the purposes of cooperation and integration. On the other hand, it implicated the politicization of regional interactions, even more visible in the case of Mercosur, which experienced the sudden increase of intra-bloc divergences (MATIUZZI DE SOUZA \& CULPI, forthcoming).

The massive presence of governments to the left of the political prism altered the regional political landscape as well as gave place to a new wave of institutional change both in structures of national governance and within regional dynamics and organisms, which is particularly visible in the case of Mercosur ${ }^{4}$. One could argue that the transformation trend initiated by the 'left turn' in South America was limited primarily to the domestic sphere of each country, especially in regards to new modes of State intervention. Nevertheless, the inter-State, intergovernmental character of South American regionalism in general - and the strong dependence on presidential diplomacy, especially in the case of Mercosur (cf. MALAMUD, 2003) - ratified the alteration in the status quo for regional policies, as leftist presidents met favorable conditions to engender a new agenda focused on the ideas of social development and regional autonomy (MATIUZZI DE SOUZA \& CULPI, forthcoming).

Among the views shared by the progressive elected presidents, it was central to the 'left agenda' the need for reformulating the role of the State, its optimal dimension, and its intervention mode (COUFFIGNAL, 2013). Although marked by a

\footnotetext{
4 Progressive presidents of member States of Mercosur elected between 2002-2014 are: Néstor Kirchner (2003) and Cristina Kirchner (2007, 2011) in Argentina; Lula da Silva (2002, 2006) and Rousseff (2010, 2014) in Brazil; Lugo (2008) in Paraguay; and Vásquez (2005) and Mujica (2010) in Uruguay. Venezuela fully joined the organism in 2012, with Chávez as president (after his decease, in 2013, Maduro assumed the position). Outside of Mercosur, the left has won presidential elections also in Bolivia, Chile, Ecuador, and Peru.
} 
high degree of heterogeneity, leftist governments agreed on the necessity of fighting inequality and underdevelopment (DABÈNE, 2012b). Similarly, they all converged on the essentiality of a more pluralized international relations with less interference of the United States and other great powers in the continent (SANTANDER, 2009). In sum, regional projects of the left were, to a certain extent, in the origin of a paradigm change, as they proposed a post-commercial, post hegemonic regionalism ${ }^{5}$. (DABÈNE, 2012a)

The redefinition of the raison d'être of the State put in motion a tendency for regulatory policies by which States designed its strategy with the objective of responding to social demands (COUFFIGNAL, 2013). The emergence of the left, in this sense, revealed "an underlying trend toward the emergence and mobilization of social and political currents" (BEASLEY-MURRAY, CAMERON \& HERSHBERG, 2010, p. 2). In the perspective of regional politics, borders and border regions became fundamental, especially for the undergoing change of Mercosur, as the intense de facto border integration and the rise of demands at the local level called for 'regulatory framework' (see DE LOMBAERDE, 2010).

The redesign of the role of the State took many forms and shapes, as different governments attempted to find a proper solution to each domestic experience. This was what the Ibero-American General Secretariat (IAGS), in the Asunción Declaration, referred to as a reform toward "comprehensive processes and strategic planning" (SECRETARIA GENERAL IBEROAMERICANA, 2011, Article 9), and also what Cervo and Bueno (2011) called 'logistic paradigm' of the State in regards to Brazilian foreign policy.

The political will to change the functioning mode of the State also raised interest on decentralization processes, by which governments would become closer to citizens and to their demands, and through which State-level decisions would be better translated into local practices (COUFFIGNAL, 2013). Historically, however, the few isolated local social policies promoted by national governments did not show to

\footnotetext{
${ }^{5}$ Even if scholars usually take Unasur and Alba as the most emblematic cases of post-hegemonic, postcommercial/post-liberal regionalism (RIGGIROZZI, 2012; SANAHUJA, 2009), one cannot ignore the institutional transformation of Mercosur in the same period and the socio-political origins of such a change that it shared with the other two regional organisms, namely the specific political and ideological synergies generated by the 'left turn' in South America.
} 
be effective for responding to the demands of local populations, let alone of citizens of Mercosur's borders and border regions.

In the period studied, South America watched a propagation of decentralized cooperation/integration projects in the heart of the majority of its regional organisms. Mercosur, in turn, searched on amplifying its involvement on the theme by creating the Advisory Forum of Municipalities, Federated States, Provinces, and Departments of Mercosur (FCCR) with the objective of connecting regional objectives of the members of the bloc with demands and aspirations of subnational entities (MERCOSUR, 2010). In sum, 'micro' scale became more relevant as the member States of Mercosur attempted to find new approaches to regional governance regarding local populations' needs at its international borders and border regions.

In the investigated years, Mercosur managed to establish a series of changes within its structure and to create new institutions to meet the regional demands. The signature of the Consenso de Buenos Aires, in 2003, by the Argentinian president Néstor Kirchner and president Lula da Silva, of Brazil, set in motion the creation of several institutions within Mercosur, based on a regional development strategy. Among them, it is important to highlight the Permanent Court of Revision (PCR), in 2004; the Structural Convergence Fund of Mercosur (Fondo para la Convergencia Estructural del Mercosur - FOCEM), in the same year; the Mercosur Parliament (Parlasur), in 2006; several working groups (to tackle sectorial cooperation); and the Social Institute of Mercosur (MATIUZZI DE SOUZA \& CULPI, forthcoming).

Mercosur's institutional reaction to regional and local demands was, nonetheless, a late and uneven response to the processes of regionalization. Although the rise of the left did trigger a new approach to regionalism and to regional cooperation/integration strategies by enlarging the scope of regional policies to include more political and social objectives, it did not translate into a deep, structural change within the institutional structure of Mercosur (MATIUZZI DE SOUZA \& CULPI, forthcoming). Furthermore, Mercosur's response failed to consider local specificities of the border regions (see in more detail in the next section). Hence, the regional organism did not achieve to further profound changes into the interactions at the local level. 
Moreover, the resultant 'overlapping regionalisms' of the 'left turn' were characterized by their fluidity in terms of ideology and of national and regional political projects (RIGGIROZZI, 2010). Regionalism, thus, coexisted with strong nationalism (CHRISTENSEN, 2007) and generated an complex rivalry for the most prominent view for the whole of South America, comprising Mercosur (CABALLERO, 2015). The entrance of Venezuela in Mercosur in 2012, in this sense, raised divergences vis-à-vis the consolidation of a single model of regionalism ${ }^{6}$, and even after his passing, president Chávez was able to perpetuate some of his ideas (see GOUVEA \& MONTOYA, 2014).

\section{The (un)changing reality at the borders}

For a long time, border regions have had a history of their own in South America. Mercosur's international borders were not different. They were neglected by politicians and were subject to policies under the logics of international limits and of national defense. With the rise of the left, however, Mercosur's members attempted to include borders and border regions into the organism's framework. Also, it is important to note that Mercosur's response to border-related issues evidenced the new role of the State in the heart of the regional organism.

The institution-building process resulted in the creation of two groups with the sole objective of promoting border integration: the Border Integration Ad Hoc Group (BIAHG), established in 2002; and the Border Integration Work Group (BIWG), created in the scope of the FCCR, in 2008. Both groups functioned under the Common Market Group (CMG), the most important decisional body of Mercosur (MATIUZZI DE SOUZA, 2015a). Within the newly added institutional structures, decentralized cooperation and local integration dynamics became important tools for the strengthening of the regional organism (cf. VIGEVANI et al., 2011). The social and political agenda of Mercosur thus reconsidered borders and border regions as targets

\footnotetext{
${ }^{6}$ Venezuela, led by Chávez, aimed at the regional leadership by proposing a more radical model of regionalism through the enlargement of its regional organism, Alba (Bolivarian Alliance for the Peoples of Our America).
} 
for public policies, initiating new processes of institutionalization of such spaces within the bloc (RHI-SAUSI \& ODDONE, 2011).

The increase of politico-ideological synergies between progressive presidents in the period studied raised 'trust' among the parties involved at the borders, as much at top-level negotiation as local-level approaches (see DE LOMBAERDE, 2010). The 'left turn' and the consequent inclusion of borders and border regions in the scope of Mercosur increased political and economic resources toward border integration, to the extent of overcoming some of the common policy challenges, which occurred more easily in bilateral relations between the bloc's members (what Mallmann and Marques (2013) refer to as "cooperative behavior").

The case of the Integrated Urban Sanitation Project of Aceguá-Brazil and Aceguá-Uruguay, funded mainly by FOCEM, and soon to be executed (URUGUAY, 2013), is the most representative example of the development of joint projects at a border region of Mercosur. The progression of the Aceguá project was more a result of the rapprochement of Brazil and Uruguay through the set of agreements called New Agenda than of the created forums for the development of border integration in Mercosur (MATIUZZI DE SOUZA, 2014;2015b). The Brazilian-Uruguayan case served as a model for Mercosur and was central in the debates that followed the negotiations within the regional organism.

Moreover, the combination of good presidential relations (which advanced bilateral cooperation) and the regional accords toward border integration in Mercosur (which placed borders and border regions under the spot of national authorities) launched the formation of a new cross-border paradigm (chiefly based on the Brazil-Uruguay border region) that led to the attempt to create a regional statute of the border, which, in turn, proved to be more contentious and time-consuming than imagined by authorities, particularly Brazil (MATIUZZI DE SOUZA, 2015a;2015b).

Indeed, as previous works indicated (FONSECA; VENTURA, 2012; ODDONE, 2014; RHI-SAUSI \& COLETTI, 2010; RHI-SAUSI \& ODDONE, 2011; SCHERMA \& OLIVEIRA, 2014), regionalism in Mercosur in the last decade was marked by the lack of coordination of policies between different national structures and also between instances of Mercosur, which showed to be a grave problem for the creation and implementation of joint policies concerning borders and border regions. Additionally, 
the problem of coordination was not limited to bilateral relations or to Mercosur's institutional bodies. The coordination problem was also present within national structures of governance (CALVENTO, 2014; VIGEVANI, 2006), as well as at the subnational, local-level international relations.

Another dilemma was the absence of appropriate institutional channels for bottom-up communication. In the case of Border Integration Ad Hoc Group (BIAHG), the top-down logic prevailed at all phases of negotiations, and Mercosur did not achieve to stay away of its top-level diplomacy institutional nature. When local voices were heard, as was the case of the Border Integration Work Group (BIWG), they did not have any weight in the decision-making process within the regional organism, even in regards to their own cases (CALVENTO, 2014; MATIUZZI DE SOUZA, 2015a).

The lack of political convergence similarly hindered institutionalized border integration within Mercosur. In the negotiations for the establishment of Mercosur's border statute, each country represented its own project. The high nationalist character of the left in South America made impossible for the bloc's members to reach an agreement on the subject (MATIUZZI DE SOUZA, 2015a). One of the consequences of Mercosur's structural problems in addressing to border regions' issues is that local authorities cannot consider taking the road of regional politics in order to meet any need. For instance, Aceguá's (Brazil) problem of attending nonBrazilian bordering populations at the national public health system required, above all, a level of lobby in the federal capital of Brasília7 . Brazilian national Health Ministry, in turn, compiled all similar cases and worked within Mercosur in order to create a new organism in the regional bloc that could regulate the procedure for all Brazilian bordering towns in accordance to their neighboring health systems. It was the creation of the Borders Integrated Health System (SIS-Fronteiras, in Portuguese), in 2005.

After almost ten years of the first agreements on the matter, SIS-Fronteiras demonstrated similar difficulties to the ones identified previously, with absence of systematic foment to cross-border exchange on public health between bordering

\footnotetext{
${ }^{7}$ Interview with PINTO, José (local politician at the border region of Brazil and Uruguay. Interview \#1. [April, 2015]. Interviewer: Gustavo Matiuzzi de Souza. Aceguá/RS, 2015. 1 arquivo .mp3 (60 min.).
} 
conurbations, low level of involvement by local populations, and big distance between original objectives and reached goals (NOGUEIRA \& FAGUNDES, 2014).

\section{Final remarks}

The 'left turn' in South America did provide a new political environment in the regional context. Likewise, it is clear that progressive governments of the period had a regional project in mind. Hence, it is possible to talk about a 'regionalism by the left', that is, a regionalism focused on socio-political dynamics to respond to the diverse and flourishing societal demands of the last decade. The institutional transformations of Mercosur - which for the first time considered, among many other issues, borders and border regions within its framework - were, in this context, the translation of this 'renewed' regionalism into a formal political project.

The political will of leftist national governments in Mercosur, however, were not enough to meet the needs for a structural reform of the organism, especially due to the mounting discomfort to the idea of losing national autonomy and sovereignty. On the contrary, the strong nationalist vein in the heart of the regionalism by the left diminished the capabilities of furthering cooperation and integration within Mercosur as well as did not improve conditions for further regionalization. Besides, the consequent absence of coordination - probably caused by a leadership problem in Mercosur (cf. MATTLI, 1999) - hindered regionalism and its effects on regionalization.

Without implementing deep reforms in the operative system of Mercosur and with the concomitant propensity to deal with local demands via bilateral relations and accords, 'regionalism by the left' did not alter the structure of governance at regional level or at local level (as it had proposed in the Consenso de Buenos Aires). In other words, the development strategy of Mercosur failed to address the issue of inequality and underdevelopment through the engenderment of regional policies.

As for the regionalization dynamics in Mercosur, particularly at the border regions, they seemed to continue residing within informal closed clusters, away from the reality of the top-level discussions and negotiations. BIWG was a good start as an 
institutionalized forum, but did not provide real opportunities to participate in the decision-making processes.

\section{References}

BEASLEY-MURRAY, Jon; Maxwell CAMERON; Eric HERSHBERG. Latin America's Left Turns: A Tour d'Horizon p.1-22. In: CAMERON, M. e HERSHBERG, E. (Ed.). Latin America's Left Turns: Politics, Policies, and Trajectories of Change. Boulder, CO: Lynne Rienner, 2010.

CABALLERO, Sergio Santos. Identity in Mercosur: Regionalism and Nationalism. Global Governance, v. 21, n. 1, p. 43-59, 2015.

CALVENTO, Mariana. La inserción Internacional de los actores subnacionales: análisis de un proceso contemporáneo. Interações, v. 15, p. 301-313, 2014.

CERVO, Amado Luiz; Clodoaldo BUENO. História da Política Exterior do Brasil. Brasília: UnB, 2011.

CHRISTENSEN, Steen Fryba. The influence of nationalism in Mercosur and in South America: can the regional integration project survive?. Revista Brasileira de Política Internacional, v. 50, p. 139-158, 2007.

COUFFIGNAL, Georges. La nouvelle Amérique latine: Laboratoire politique de l'Occident. Paris: Presses de Science Po, 2013.

DABÈNE, Olivier. Au-delà du régionalisme ouvert: la gauche latino-américaine face au piège de la souveraineté e de la flexibilité. In: DABÈNE, O. (Ed.). La gauche en Amérique latine. Paris: Presses de Science Po, 2012a.

Introduction: La gauche latino-américaine en action. In: DABÈNE, O. (Ed.). La gauche en Amérique latine (1998-2012). Paris: Presses de Sciences Po, 2012b.

DE LOMBAERDE, Philippe. How to 'connect' micro-regions with macro-regions? A Note. Perspectives on Federalism, v. 2, n. 3, p. 29-37, 2010.

FONSECA, Marcela Garcia; Deisy VENTURA. Cooperación descentralizada e integración regional: ¿contraposición o complementariedad? Los entes subnacionales en la Unión Europea y en Mercosur. TIP - Trabajos de Investigación en Paradiplomacia, v. 1, p. 39-54, 2012.

GOUVEA, Raul; Manuel MONTOYA. Mercosur After Chavez. Thunderbird International Business Review, v. 56, n. 6, p. 563-575, 2014.

HEYMAN, Josiah M; John SYMONS. Borders p.540-557. In: FASSIN, D. (Ed.). $A$ Companion to Moral Anthropology. Chichester - UK: John Wiley \& Sons, 2012.

MALAMUD, Andrés. Presidentialism and Mercosur: A Hidden Cause for A Successful Experience p.53-73. In: LAURSEN, F. (Ed.). Comparative Regional Integration: Theoretical Perspectives. Aldershot: Ashgate, 2003. 
MALLMANN, Maria Izabel; Teresa Cristina Schneider MARQUES. A crise do multilateralismo e o Mercosul: O surgimento de uma nova lógica de integração? 4ํㅜ Encontro Nacional da Associação Brasileira de Relações Internacionais. Belo Horizonte, 2013.

MATIUZZI DE SOUZA, Gustavo. Demandas por regulação na região fronteiriça brasilo-uruguaia. Século XXI, v. 5, n. 2, p. 13-32, 2014.

. The institutionalization process of border integration in Mercosur (20032015). I International Workshop on Regionalism and Integration Processes in Latin America. Université de Liège. Liège, Belgium, 2015a.

Parceria estratégica Brasil-Uruguai no contexto da inserção internacional brasileira (2003-2014). Monções, v. 4, n. 7, p. 165-185, 2015 b.

MATIUZZI DE SOUZA, Gustavo; Ludmila CULPI. La réinvention du Mercosur à la lumière des synergies politico-idéologiques sud-américaines. In: SANTANDER, S. (Ed.). Concurrences régionales dans un monde multipolaire émergent. Bruxelles: Peter Lang, forthcoming.

MATTLI, Walter. The Logic of Regional Integration: Europe and Beyond. Cambridge: Cambridge University Press, 1999.

MERCOSUR. Foro Consultivo de Municípios, Estados Federados, Províncias e Departamentos do Mercosul - FCCR: Presidência Pro Tempore Brasileira 2010. Foz do Iguaçú: Secretaria de Relações Institucionais, 2010.

NOGUEIRA, Vera Maria Ribeiro; Helenara Silveira FAGUNDES. A implementação do SIS Fronteiras: Perspectivas para a ampliação do direito à saúde na fronteira arco sul. Serviço Social \& Saúde, v. 13, n. 2, p. 245-260, 2014.

ODDONE, Nahuel. Cooperación Transfronteriza en América Latina: Una aproximación teórica al escenario centroamericano desde la experiencia del Proyecto Fronteras Abiertas. Oikos, v. 13, n. 2, p. 129-144, 2014.

RHI-SAUSI, José Luis; Raffaella COLETTI. Cross-border regional integration and cooperation in Latin America: experiences and perspectives. Year book for decentralised cooperation. Montevideo: Observatorio de Cooperación Descentralizada Unión Europea - América Latina: 182-204 p. 2010.

RHI-SAUSI, José Luis; Nahuel ODDONE. La cooperación transfronteriza entre las unidades subnacionales del Mercosur p.203-217. In: CERQUEIRA FILHO, G. (Ed.). Sulamérica - comunidade imaginada: emancipação e integração. Niterói (RJ): EdUFF, 2011.

RIGGIROZZI, Pia. Region, Regionness and Regionalism in Latin America: Towards a New Synthesis. Latin America Trade Network. Working Paper \#130: University of Southamptom, 2010.

RIGGIROZZI, Pia; Diana TUSSIE. The Rise of Post-Hegemonic Regionalism: the Case of Latin America. London, New York: Springer, 2012.

SANAHUJA, José Antonio. Del regionalismo abierto al regionalismo post-liberal. Crisis y cambio en la integración regional en América Latina. Anuario de la integración regional de América Latina y el Gran Caribe, v. 7, p. 12-54, 2009. 
SANTANDER, Sebastian. El 'giro a la izquierda' en América Latina: Fragmentación y recomposición de la geopolítica regional. Cuadernos sobre Relaciones Internacionales, Regionalismo y Desarrollo, v. 4, n. 7, p. 17-38, 2009.

SCHERMA, Márcio Augusto; Jussara Pereira de OLIVEIRA. Integração na fronteira Brasil-Uruguai na área da saúde: um panorama. Quinto Congreso Uruguayo de Ciencia Política: ¿Qué ciencia política para qué democracia? Montevideo: Asociación Uruguaya de Ciencia Política, 2014.

SECRETARIA GENERAL IBEROAMERICANA. Declaración de Asunción. Asunción, Paraguay, 2011.

SÖDERBAUM, Fredrik. Rethinking regions and regionalism. Georgetown Journal of International Affairs, v. 14, n. 2, p. 9-18, 2013.

URUGUAY. Gobiernos de Uruguay y Rio Grande do Sul acordaron obras de saneamiento en Aceguá. 2013.2 Disponível em: < http://presidencia.gub.uy/comunicacion/comunicacionnoticias/saneamientoacegua $>$. Acesso em: 10/11/15.

VIGEVANI, Tullo. Problemas para a atividade internacional das unidades subnacionais: estados e municípios brasileiros. Revista Brasileira de Ciências Sociais, v. 21, p. 127-139, 2006.

VIGEVANI, Tullo et al. Actores locales, cooperación descentralizada y fortalecimiento institucional: posibilidades de profundización del Mercosur. Anuario de la Cooperación Descentralizada, v. 6, p. 146-168, 2011. 